\title{
HNF1 $\alpha$ inhibition triggers epithelial-mesenchymal transition in human liver cancer cell lines
}

Laura Pelletier ${ }^{1,2}$, Sandra Rebouissou ${ }^{1,2}$, Danijela Vignjevic ${ }^{3}$, Paulette Bioulac-Sage ${ }^{4,5}$ and Jessica Zucman-Rossi ${ }^{1,2,6^{*}}$

\begin{abstract}
Background: Hepatocyte Nuclear Factor $1 \alpha(\mathrm{HNF} 1 \alpha)$ is an atypical homeodomain-containing transcription factor that transactivates liver-specific genes including albumin, $\alpha-1$-antitrypsin and $\alpha$ - and $\beta$-fibrinogen. Biallelic inactivating mutations of HNF1A have been frequently identified in hepatocellular adenomas (HCA), rare benign liver tumors usually developed in women under oral contraceptives, and in rare cases of hepatocellular carcinomas developed in non-cirrhotic liver. HNF1 $\alpha$-mutated HCA (H-HCA) are characterized by a marked steatosis and show activation of glycolysis, lipogenesis, translational machinery and mTOR pathway. We studied the consequences of HNF1 $\alpha$ silencing in hepatic cell lines, HepG2 and Hep3B and we reproduced most of the deregulations identified in H-HCA.
\end{abstract}

Methods: We transfected hepatoma cell lines HepG2 and Hep3B with siRNA targeting HNF1 $\alpha$ and obtained a strong inhibition of HNF1 $\alpha$ expression. We then looked at the phenotypic changes by microscopy and studied changes in gene expression using qRT-PCR and Western Blot.

Results: Hepatocytes transfected with HNF1 $\alpha$ siRNA underwent severe phenotypic changes with loss of cell-cell contacts and development of migration structures. In HNF1 $\alpha$-inhibited cells, hepatocyte and epithelial markers were diminished and mesenchymal markers were over-expressed. This epithelial-mesenchymal transition (EMT) was related to the up regulation of several EMT transcription factors, in particular SNAIL and SLUG. We also found an overexpression of TGF $\beta 1$, an EMT initiator, in both cells transfected with HNF1 $\alpha$ siRNA and H-HCA. Moreover, TGF $\beta 1$ expression is strongly correlated to HNF1 $\alpha$ expression in cell models, suggesting regulation of TGF $\beta 1$ expression by HNF1 $\alpha$.

Conclusion: Our results suggest that HNF1 $\alpha$ is not only important for hepatocyte differentiation, but has also a role in the maintenance of epithelial phenotype in hepatocytes.

Keywords: Hepatocyte Nuclear Factor 1 $\alpha$ ? $a$ ?, hepatocellular adenoma, tumor suppressor gene, benign tumor, siRNA, EMT, TGFß $3 \beta$ ? 1

\section{Background}

Hepatocyte Nuclear Factor $1 \alpha(\mathrm{HNF} 1 \alpha)$ is an atypical homeodomain-containing protein that was originally identified as a hepatocyte-specific transcriptional regulator [1]. In vivo and in vitro models of HNF1 $\alpha$ inactivation demonstrated that this transcription factor plays an important role in hepatocyte differentiation and is also crucial for metabolic regulation and liver function [2-5]. Biallelic mutations of HNF1A have been identified in about $35 \%$ of hepatocellular adenomas (HCA), rare

\footnotetext{
* Correspondence: zucman@cephb.fr

'Inserm U674 Génomique fonctionnelle des tumeurs solides, Paris, France Full list of author information is available at the end of the article
}

benign liver tumors usually occurring in young women under oral contraceptives, and in rare cases of hepatocellular carcinomas developed in non-cirrhotic liver [6-8]. Recently, HCA has been described as a heterogeneous disease including at least three main subtypes of tumors in which pathological phenotypes are closely related with specific genetic alterations and clinical features [8-12]. HNF1 $\alpha$-mutated HCA (H-HCA) are phenotypically characterized by a marked steatosis [7-9]. In $90 \%$ of the cases, $\mathrm{H}-\mathrm{HCA}$ are sporadic lesions displaying somatic mutations. However, in rare families with an inherited mutation in one allele of HNF1A, MODY3 (Maturity $\underline{\text { Onset }}$ Diabetes of the Young type 3) patients
C Biomed Central

() 2011 Pelletier et al; licensee BioMed Central Ltd. This is an Open Access article distributed under the terms of the Creative Commons Attribution License (http://creativecommons.org/licenses/by/2.0), which permits unrestricted use, distribution, and reproduction in any medium, provided the original work is properly cited. 
are predisposed to develop familial liver adenomatosis that is defined by the presence of more than $10 \mathrm{HCA}$ nodules in the liver [7,13-16]. Thus, HNF1A meets the genetic criteria of a tumor suppressor gene [7].

To gain insight into the tumorigenic mechanisms related to HNF $1 \alpha$ inactivation, we performed a transcriptomic analysis of $\mathrm{H}-\mathrm{HCA}$ and identified pathways aberrantly activated in these tumors $[17,18]$. Previously, we have shown an aberrant activation of glycolysis and lipogenesis, independent of SREBP-1 and CHREBP, that could explain the steatotic phenotype of these tumors. We also identified an activation of mTOR pathway and of the translational machinery, along with an overexpression of several growth factors and oncogenes. We assessed in vitro the role of HNF1 $\alpha$ in the observed deregulations by inhibiting its endogenous expression in human liver cancer cell lines using small interfering RNA. Here, we analyse the phenotypic consequences of HNF1 $\alpha$ inhibition in two hepatic cell lines, HepG2 and Hep3B.

\section{Methods}

\section{Cell lines and siRNA transfection}

HepG2 and Hep3B cells were obtained from the American Type Culture Collection and were cultured in Dulbecco's Modified Eagle Medium with high glucose (Invitrogen) supplemented with 10\% fetal calf serum, penicillin $100 \mathrm{IU} / \mathrm{ml}$ and streptomycin $100 \mu \mathrm{g} / \mathrm{ml}$. SiRNA transfections were performed, as decribed previously [17], according to the manufacturer's protocol, in 6 well-plates using the lipofectamine RNAiMax reagent (Invitrogen) with siRNA duplexes targeting HNF1A (NM_000545) (Ambion) with sequence: GGUCUUCACCUCAGACACUtt (exon 8-9 3544). Block-iT Alexa Fluor Red Fluorescent Oligo siRNA (Invitrogen) was used as a double-stranded RNA negative control. In most experiments $10 \mathrm{nM}$ of each siRNA was transfected in triplicate, except for dose-effect studies, where several siRNA concentrations were tested $(0,0.01,0.05,0.1,0.2$, $0.4,0.6,0.8,1,5,10$ and $50 \mathrm{nM}$ ) in order to obtain different levels of HNF1A expression. Cells were prepared for analyses either 3 or 7 days after transfection for HepG2 cells but only after 3 days for Hep3B cells, because HNF $1 \alpha$ inhibition could not be maintained until 7 days in this cell line. The absence of cross-reaction of the HNF1 $\alpha$-siRNA duplexes with the $H N F 1 B$ sequence was checked by comparing the expression level of HNF1A transcript in cells transfected with siRNA targeting HNF1A with the control siRNA-transfected cells.

\section{Quantitative RT-PCR}

Quantitative RT-PCR (qRT-PCR) was performed in duplicate as previously described [19] using pre- designed primers and probe sets from Applied Biosystems (Additional file 1). Ribosomal 18S (R18S) was used for the normalization of expression data and the $2^{-\Delta \Delta C T}$ method was applied. The final results were expressed as the fold differences of target gene expression in HNF1 $\alpha$ siRNA compared with control siRNA in cell lines or in tested samples compared with the mean expression value of normal tissues for tumor analysis.

\section{Western blotting}

Western blot analyses were performed as previously described [18] using the primary antibodies specific for E-Cadherin (Cell Signaling Technology, diluted 1:100), HNF1 $\alpha$, Vimentin and N-Cadherin (Santa Cruz Biotechnology, 1:500, 1:200 and 1:200); Polyclonal rabbit antiactin (Sigma, 1:3000) was used as loading control.

\section{Immunofluorescence}

Cells were grown on slides for 3 or 7 days and fixed with 4\% formaldehyde in phosphate-buffered saline (PBS) $1 \mathrm{X}$ for $15 \mathrm{~min}$. After washing with PBS, cells were permeabilized with $0.1 \%$ triton for $15 \mathrm{mn}$, washed with PBS, then, cells were incubated with primary antibody overnight. After three washes with PBS, cells were incubated with secondary antibodies for $1 \mathrm{~h}$. The slides were washed, then mounted with VECTASHIELD ${ }^{\circledR}$ Mounting Medium with DAPI (Vector Laboratories). Immunofluorescence images were obtained using a Carl Zeiss Axiophot microscope. All images within one experiment were collected using $63 \mathrm{x}$ objective and the same exposure time. The antibodies used were: rabbit anti-E-cadherin (Santa Cruz Biotechnology, 1:100), rabbit anti-Ncadherin (Santa Cruz Biotechnology, 1:100), rabbit antiFibronectin (Sigma, 1:100), and the secondary antibodies were anti-mouse and anti-rabbit (GE Healthcare, 1:100, 1:100). Actin was stained by incubating cells for $1 \mathrm{~h}$ with Alexa Fluor 488 phalloidin (Molecular Probes, $1: 300)$.

\section{Migration assays}

Boyden chamber migration assays were performed $72 \mathrm{~h}$ after transfection using 24-well migration inserts (BD Biosciences). 1,5 × $10^{5}$ cells were plated in the upper chamber of the migration insert and they were left to migrate towards medium with serum for $16 \mathrm{~h}$. Cells on the upper side of the insert membrane were removed with a cotton swab, whereas cells that had migrated to the underside of the insert membrane were fixed with $4 \%$ formaldehyde in phosphate-buffered saline (PBS) for 15 min. After washing with PBS, cells were permeabilized with $0.1 \%$ triton for $15 \mathrm{~min}$, washed with PBS, and stained with hematoxylin. Cells were counted under 300x magnified field, 10 fields were counted for each condition and each condition was done in triplicates. 


\section{Wound-healing assays}

HepG2 cells were seeded and transfected in 6-well plates at the density of $5 \times 10^{5}$ cells per well. After 48 $h$, a scratch was made through confluent cells with a pipette tip and cells were washed with PBS, and medium without serum was added. Picture $\&+s$ were taken just after the scratch was made and at 24, 48 and $72 \mathrm{~h}$ afterwards, to monitor cell movements. The experiment was reproduced three times.

\section{Time lapse microscopy}

HepG2 cells transfected with Control or HNF1 $\alpha$ siRNA for 3 days in glass-bottom dishes were imaged using 20x objective and Biostation IM at Nikon Imaging Centre at Institut Curie, Paris. Cells were incubated overnight (during 16-18 h) in the Biostation IM and Images were collected every 10 minutes during 16-18 h. The experiment was repeated three times. Data were analysed using MetaMorph image analysis software.

\section{Patients and samples}

Liver tissues were collected in nine French surgery departments from 1992 to 2004. They were immediately frozen in liquid nitrogen and stored at $-80^{\circ} \mathrm{C}$ until used for molecular studies. The whole series of HCA used for the different molecular analyses included $35 \mathrm{H}-\mathrm{HCA}$ previously described $[8,9,17]$, and 23 normal livers taken from patients resected with primary liver tumors developed in the absence of cirrhosis. All the patients were recruited in accordance with French law and institutional ethical guidelines. The study was approved by the ethical committee of Hôpital Saint-Louis, Paris, France.

\section{Statistical analysis}

All the values reported are mean \pm SD. Statistical analyses were performed using GraphPad Prism version 5 software and significance was determined using either the nonparametric Mann-Whitney test for unpaired data or the two-tailed t-test. Difference was considered significant at $P<0.05$. In all graphs, ***; $* *$ indicate difference between groups at $P<0.05,0.01$ and 0.001 , respectively.

\section{Results}

HNF1 $\alpha$ silencing impairs epithelial phenotype of hepatocyte tumor cells HepG2 and Hep3B

HepG2 et Hep3B cell lines were transfected with siRNA targeting exon 8-9 of HNF1A or control siRNA, as previously described [17]. HNF1A mRNA inhibition reached $98 \%$ and was maximal at $72 \mathrm{~h}$ after transfection, as well as the expression of its transactivated gene FABP1 [17]. Silencing of HNF1 $\alpha$ lasted until 7 days in HepG2, but was not maintained beyond 3 days in Hep3B. Expression of HNF1 $\alpha$ homologue, HNF1 $\beta$, was not diminished by HNF1 $\alpha$ siRNA at 24 and 48 h after transfection, assessing that HNF1 $\alpha$ siRNA did not target HNF1 $\beta$ mRNA (Additional File 2A).

Cells transfected with HNF1 $\alpha$ siRNA had a different phenotype from cells transfected with control siRNA. On phase contrast microscopy, they looked elongated and had lost cell-cell contacts (Figure 1A). This phenotype was maintained until at least 7 days after transfection in HepG2 cells. Phalloidin labelling revealed reorganized actin cytoskeleton with development of actin structures looking like lamelipodia and filopodia in both cell type (Figure 1B). Time-lapse microscopy of HepG2 cells transfected with HNF1 $\alpha$ siRNA showed that the cytoplasmic protrusions observed in those cells were dynamic structures protruding from the cell (Figure $1 \mathrm{C})$.

Expression of albumin, a liver-specific gene, and of transcription factors involved in hepatocyte differentiation, assessed by quantitative RT-PCR (qRT-PCR), was diminished 3 days after transfection in both cell type, and was maintained low until at least 7 days after transfection in HepG2 (Figure 1D and 1E). Particularly, HNF4 $\alpha$ expression, which has been shown to be regulated by HNF1 $\alpha[20,21]$, was decreased early after transfection and this decrease was strongly correlated to HNF1 $\alpha$ expression, which was modulated by using several concentrations of siRNA (Additional files $2 \mathrm{~A}$ and $2 B)$. These results revealed dedifferentiation of cells transfected with HNF1 $\alpha$ siRNA.

\section{Epithelial markers are under expressed and mesenchymal markers are overexpressed in HNF1 $\alpha$-siRNA-transfected cells}

Epithelial-mesenchymal transition (EMT) is defined by loss of epithelial cell polarity, disappearance of differentiated junctions, reorganization of the cytoskeleton and changes in migration abilities [22-25]. During this process, epithelial markers such as E-cadherin are under expressed and mesenchymal markers are over expressed. In HepG2 cells transfected with HNF1 $\alpha$ siRNA, E-cadherin is strongly under expressed at the transcription level as well as at protein level (Figure 2A and 2B). Immunostaining of E-cadherin showed presence at cellcell junctions in control-siRNA-transfected cells whereas cells transfected with HNF1 $\alpha$ siRNA showed no staining at cell borders, suggesting loss of adherens junction in those cells (Figure 2C). Interestingly, the decrease of Ecadherin mRNA was significantly correlated to HNF1 $\alpha$ mRNA decrease, when it was modulated using a range of siRNA (Additional file 3). Moreover, zonula occludens-1 (ZO-1), a tight-junction protein, was also under expressed at transcriptional level (Figure 2A). In HNF1 $\alpha$-inhibited HepG2 cells, the mesenchymal markers vimentin and fibronectin were over expressed both 

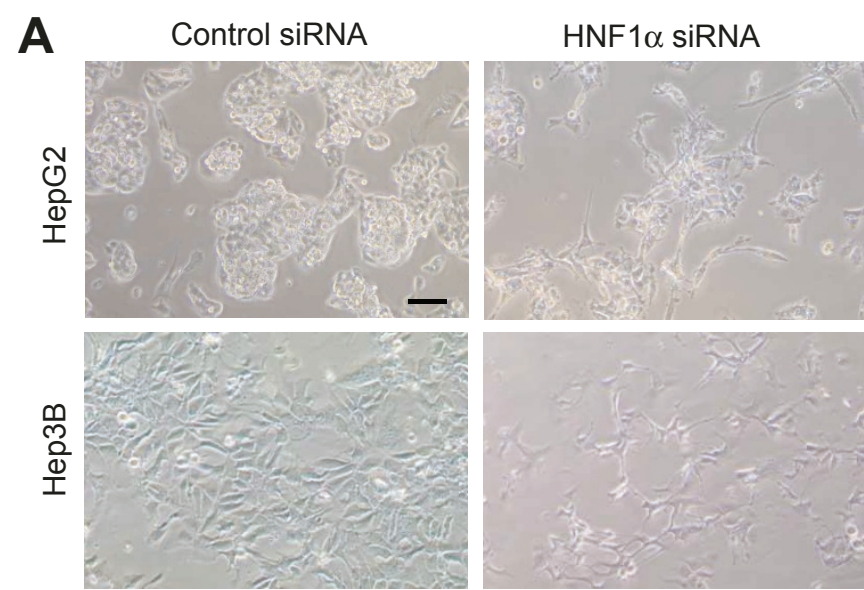

B
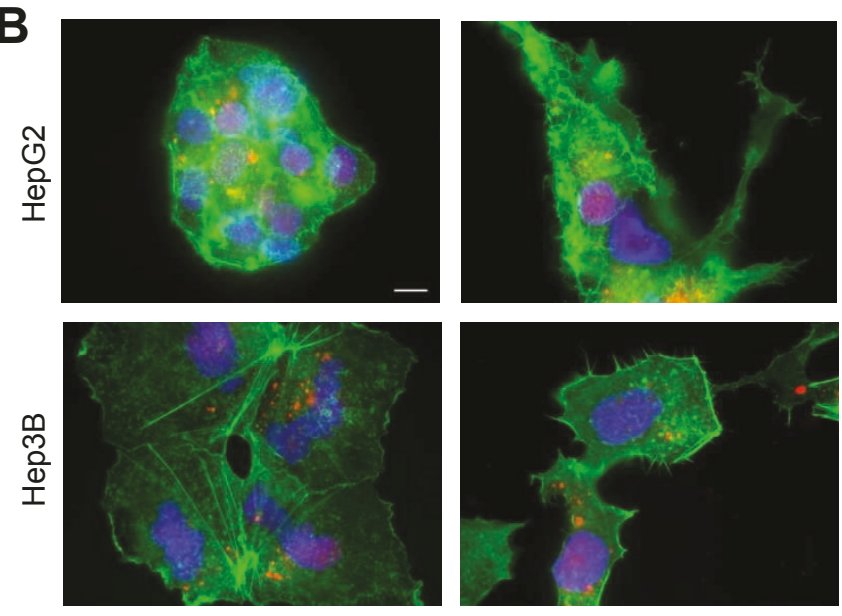

C

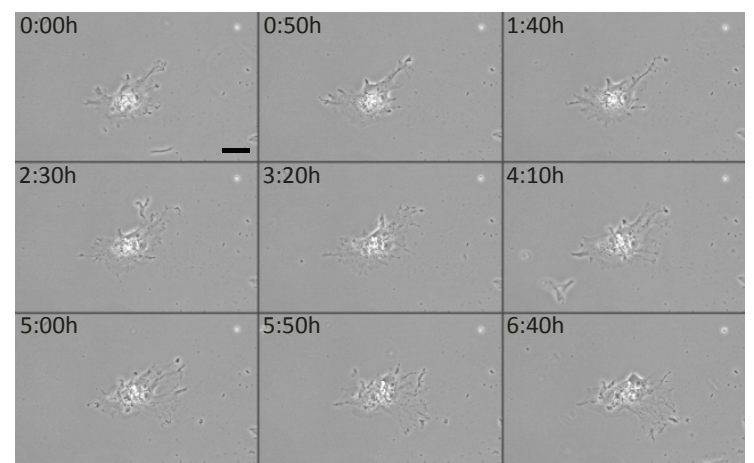

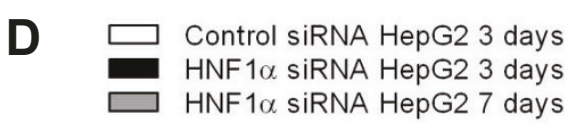

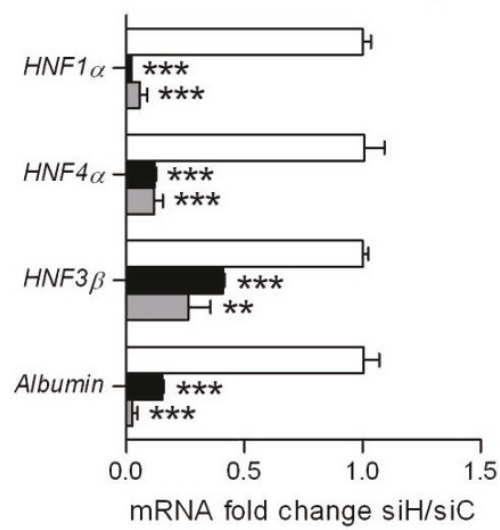

E Control siRNA Hep3B 3days HNF1 $\alpha$ siRNA Hep3B 3 days

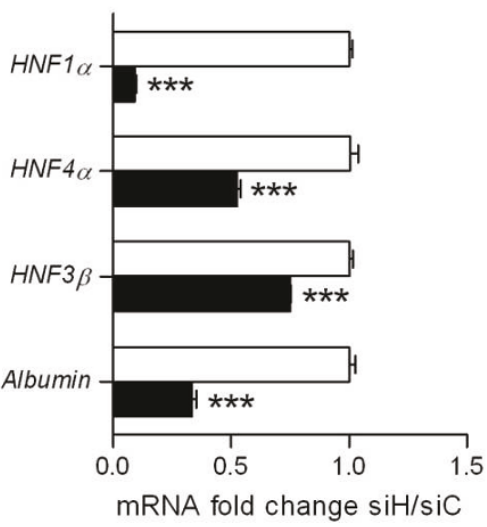

HNF $1 \alpha$ siRNA

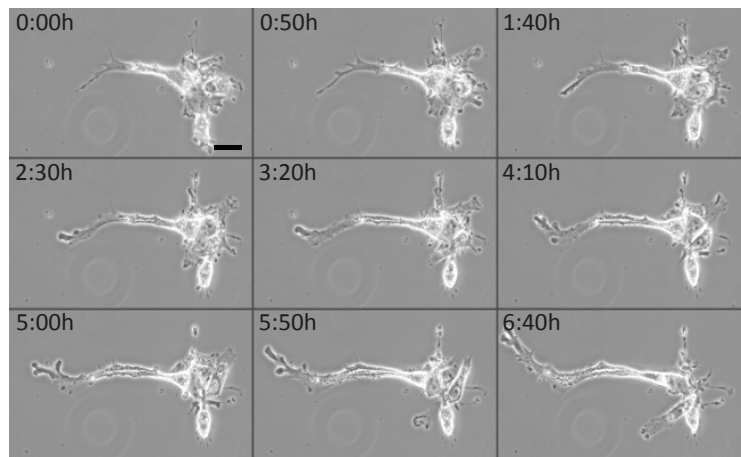

Figure 1 Loss of epithelial phenotype and development of dynamic structures of migration in HepG2 and Hep3B cells transfected with HNF1 $\alpha$ siRNA. HepG2 and Hep3B cells were transfected with $10 \mathrm{nM}$ of HNF1 $\alpha$ siRNA (siH) or with a control siRNA (siC). A: Morphology of transfected HepG2 and Hep3B cells obtained by phase-contrast microscopy with a 10X objective after $72 \mathrm{~h}$. Scale bar $100 \mu \mathrm{m}$. B: Actin stained using phalloidin (green) in HepG2 and Hep3B cells transfected with fluorescent control siRNA (red) or co-transfected with fluorescent control and HNF1 $\alpha$ siRNA after $72 \mathrm{~h}$. DNA is stained using DAPI (blue). Scale bar $10 \mu \mathrm{m}$. C: Time-lapse imaging showing dynamic cytoplasmic protrusions in HepG2 cells transfected with HNF1 $\alpha$ siRNA compared to cells transfected with control siRNA, $72 \mathrm{~h}$ after transfection. Only 1 image every 50 min is shown here. Scale bar $20 \mu \mathrm{m}$. D, E: Expression of transcription factors involved in hepatocyte differentiation and of albumin, a marker of hepatocellular differentiation, in HepG2 (D) and Hep3B (E) cells transfected with HNF1 $\alpha$ siRNA after 3 and 7 days for HepG2, compared with cells transfected with control siRNA. mRNA levels were analyzed by qRT-PCR and are expressed as n-fold difference in gene expression of HepG2 cells transfected with HNF1 $\alpha$ siRNA (siH) relative to cells transfected with control siRNA (siC) (two-tailed t-test). 


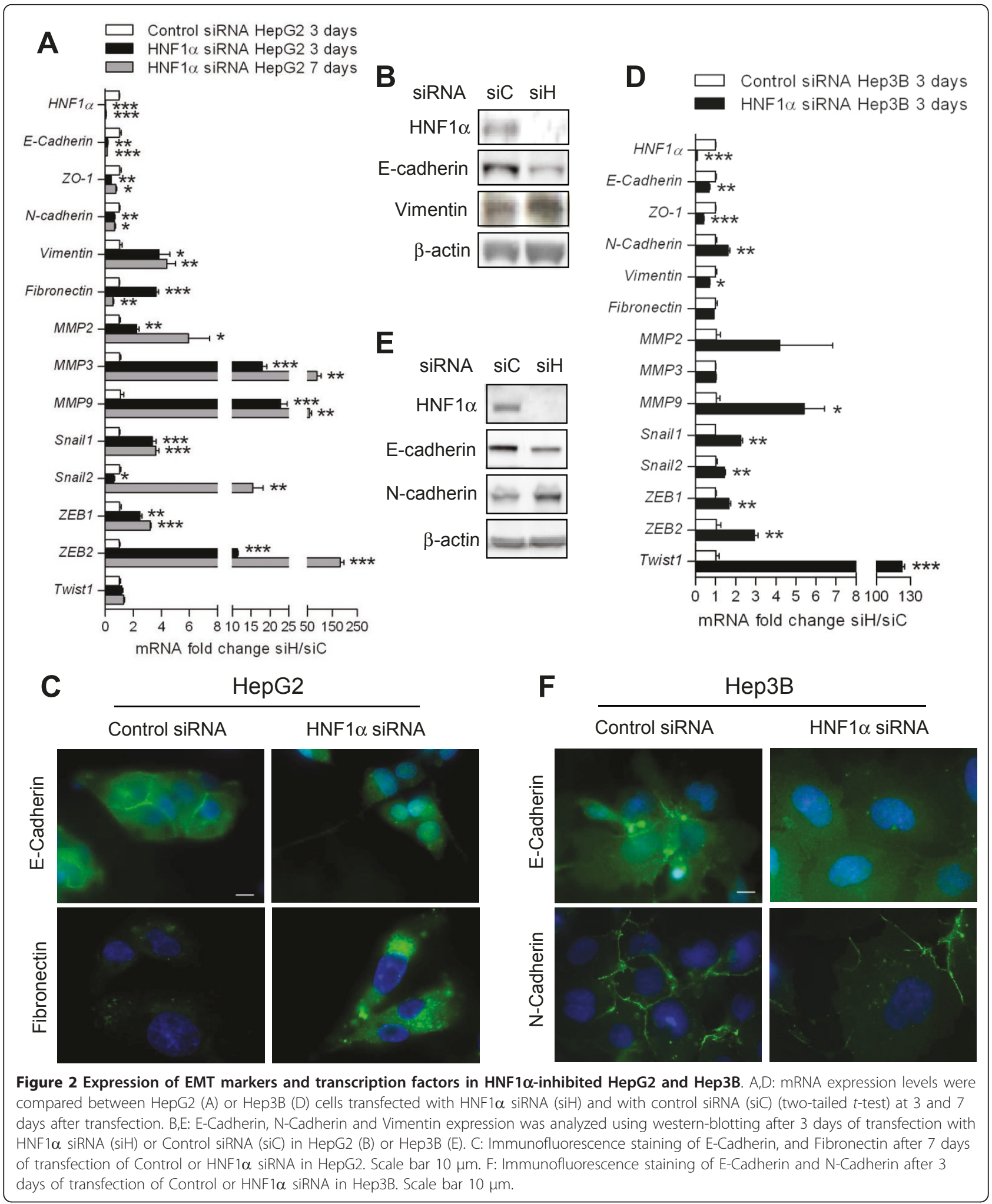


at RNA and protein levels (Figure 2A, B and 2C). Several proteins involved in bassement membrane degradation, metalloproteinases (MMP) 2, 3 and 9, were also over expressed in HepG2 cells transfected with HNF1 $\alpha$ siRNA (Figure 2A). These characteristics of EMT were observed at 3 days after transfection and were mostly maintained until 7 days.

In Hep3B cell line, epithelial markers were also under expressed and E-cadherin staining was not found at cell border in cells transfected with HNF1 $\alpha$ siRNA (Figure $2 \mathrm{D}, \mathrm{E}$ and $2 \mathrm{~F}$ ). However, the mesenchymal markers over expressed in Hep3B were not the same than in HepG2 cell line. Vimentin and fibronectin remained unchanged whereas $\mathrm{N}$-cadherin was up regulated at RNA and protein levels in Hep3B cells transfected with HNF1a siRNA (Figure 2D and 2E). Overexpression of N-cadherin was not obvious by immunofluorescence analysis, but $\mathrm{N}$-cadherin was mostly found at cell borders and cell-cell contacts were diminished in HNF1 $\alpha$-siRNAtransfected cells (Figure 2F). Finally, metalloproteinase 9 was also significantly over expressed in Hep3B cells transfected with HNF1 $\alpha$ siRNA (Figure 2D).

Overall, liver cancer cells transfected with HNF1 $\alpha$ siRNA lost expression of epithelial and tight junction markers and over expressed proteins usually expressed in mesenchymal cells, defining an epithelial-mesenchymal transition in those cells.

\section{Overexpression of transcription factors involved in EMT}

Several transcription factors have been involved in the establishment of epithelial-mesenchymal transition, and in particular, in the repression of E-cadherin expression. These transcription factors are usually up regulated during EMT [22-24]. Among these proteins, the Snail family members (Snail1 and Snail2, also known as Snail and Slug) play a key role in EMT. Snail1 was up regulated in HepG2 cells transfected with HNF1 $\alpha$ siRNA compared with control siRNA, at 3 days after transfection and until 7 days (Figure 2A). Snail2 was slightly under expressed at 3 days after transfection but it was importantly over expressed at 7 days. The transcription factors of the ZEB family, and particularly ZEB2, were over expressed in HepG2 cells transfected with HNF1 $\alpha$ siRNA at 3 and 7 days after transfection (Figure 2A). Up regulation of all these transcription factors was also observed in Hep3B cells, along with the overexpression of Twist1, another transcription factor involved in EMT (Figure 2D).

\section{HNF1 $\alpha$ silencing enhances migration of HepG2 cell line}

We performed several experiments to assess the ability of migration of HNF1 $\alpha$-inhibited HepG2 cells. First, we put the cells transfected with HNF1 $\alpha$ siRNA deprived with serum in a migration insert and let them migrate four $16 \mathrm{~h}$ towards medium with serum. More cells were able to migrate when they where transfected with HNF1 $\alpha$ siRNA than with control siRNA (Figure 3A).

In a wound healing assay, the scratch caused in cells tranfected with control siRNA did not close completely, even after $72 \mathrm{~h}$ (Figure 3B). In HepG2 cells transfected with HNF1 $\alpha$ siRNA, the wound did not close completely either but HNF1 $\alpha$-inhibited cells were able to move at the center of the wound unlike control cells (Figure 3B).

Those results showed that HepG2 cells transfected with HNF $1 \alpha$ siRNA developed greater migration abilities than control cells.

TGF $\beta 1$ is over expressed in HNF1 $\alpha$-inhibited cells and in HNF1 $\alpha$-mutated hepatocellular adenomas

Many proteins can trigger epithelial-mesenchymal transition $[23,24]$. Among them, we found that TGF $\beta 1$ was over expressed in HepG2 and Hep3B cells transfected with HNF1 $\alpha$ siRNA (Figure 4A and 4B). Moreover, the overexpression of TGF $\beta 1$ mRNA was inversely correlated to HNF1 $\alpha$ expression in HepG2 cells (Figure 4C). We then studied the transcriptomic expression of two genes that are known to be induced by TGF $\beta / \mathrm{Smad}$ pathway: $S M A D 7$, an inhibitor of TGF $\beta$ pathway that is Smad-regulated and is induced by TGF $\beta$ in an early response $[26,27]$, and TGF $\beta$-induced (TGFBI), an extracellular matrix protein which plays a role in cell-collagen interactions [28]. SMAD7 and TGFBI were upregulated at 3 and 7 days after transfection in HepG2 (Figure 4A) and in Hep3B cell lines (Figure 4B). These results suggest that $\mathrm{TGF} \beta$ pathway is activated in HNF1 $\alpha$-inhibited cells and could participate to the EMT observed in these cells.

Interestingly, we found an overexpression of TGF $\beta 1$ in H-HCA compared to normal livers by quantitative RTPCR (Figure 4D). But we couldn't find any proof of TGF $\beta$ pathway activation in these tumors, since neither SMAD7 nor TGFBI were over expressed, nor any other known TGF $\beta$ pathway target genes (Figure 4D, E and data not shown).

\section{Discussion}

HNF1 $\alpha$ is a transcription factor involved in hepatocyte differentiation and is important for normal liver function. Here, we show that HNF1 $\alpha$ might also be important for maintenance of epithelial phenotype in hepatocytes. Liver cancer cell lines in which HNF1 $\alpha$ expression was inhibited by siRNA underwent an epithelial-mesenchymal transition and lost hepatocyte differentiation and epithelial phenotype. Expression of proteins involved in tight and adherens junctions, like ZO-1 and E-cadherin, was diminished, leading to loss of cell-cell contacts and reorganization of cytoskeleton. 


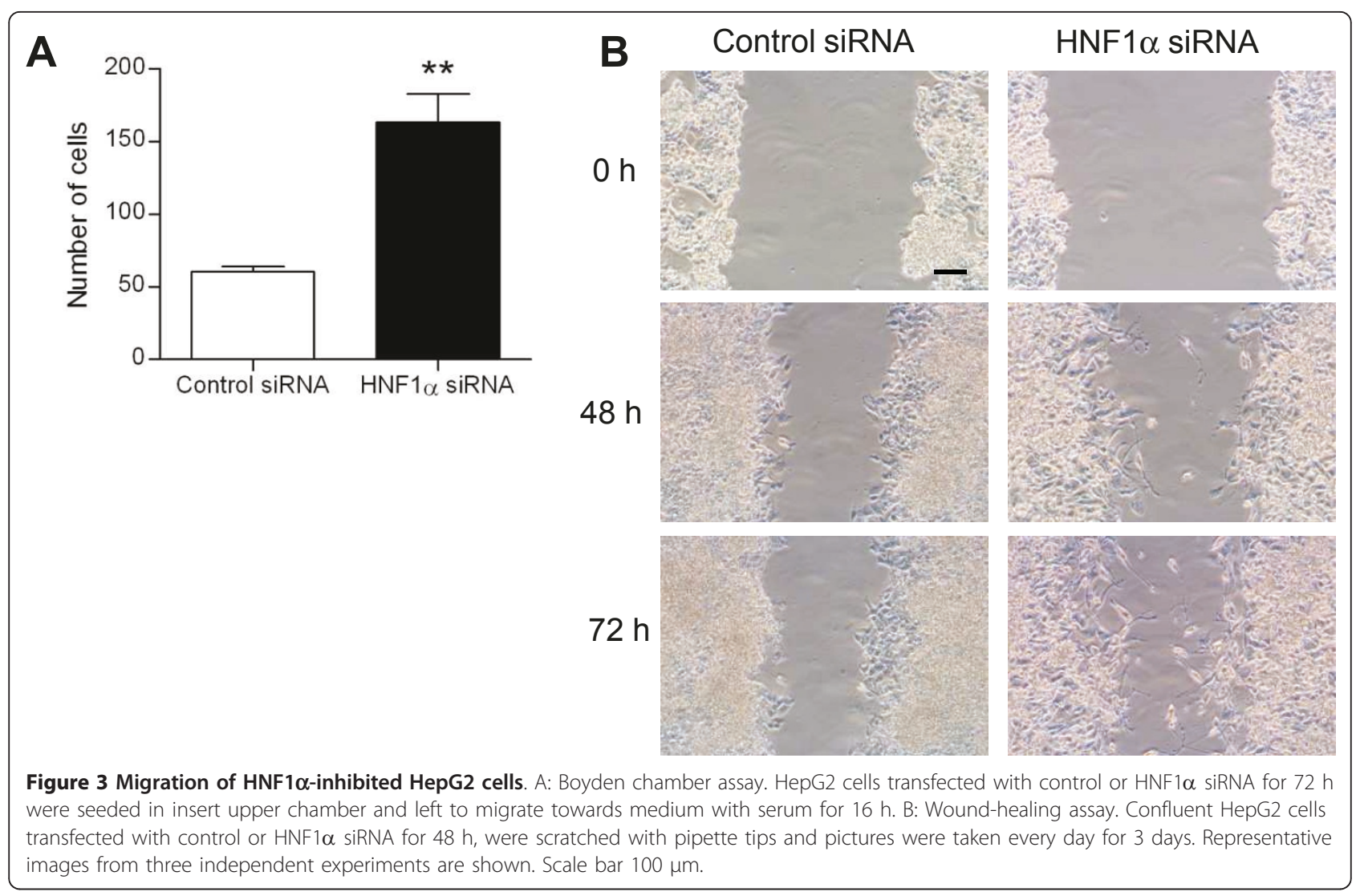

Cells transfected with HNF1 $\alpha$ siRNA also showed an overexpression of mesenchymal markers and of several key transcription factors involved in EMT development, in particular Snail1 and Snail2.

Under-expression of E-cadherin has previously been described in a mouse model of HNF1 $\alpha$ inactivation. In this mouse model in which pancreatic $\beta$-cell over expressed a dominant-negative mutant of $\mathrm{HNF} 1 \alpha$, pancreatic islets showed abnormal architecture with, in particular, a reduced expression of E-cadherin [29]. It was then suggested that E-cadherin could be a target of HNF1 $\alpha$. A putative HNF1 $\alpha$ binding site was found in intron 2 of human E-cadherin gene and HNF1 $\alpha$ acts as an enhancer on the chicken E-cadherin gene but further studies are required to understand the regulation of $\mathrm{E}$ cadherin by HNF1 $\alpha$. Our results showed a strong correlation between E-cadherin and HNF1 $\alpha$ expression, supporting the hypothesis of a regulation of E-cadherin expression by HNF1 $\alpha$, whether direct or indirect. HNF1 $\alpha$ has also been shown to be a positive regulator of other molecules of cellular junctions, tight junction component claudin-2 [30] and gap junction protein connexin32 [31].

The HNF1 homeoprotein family contains another member apart from HNF1 $\alpha$, HNF $1 \beta$. HNF $1 \alpha$ and HNF1 $\beta$ are highly homologous protein that can recognize the same binding site and form heterodimers [32]. They are both expressed in the polarized epithelium of several tissues (liver, kidney, pancreas and digestive tract), though in a sequential manner, which led to the assumption that they could be involved in epithelial differentiation [33]. In the liver, HNF1 $\beta$ is expressed earlier during development but in adult hepatocytes HNF $1 \alpha$ is predominant, whereas HNF1 $\beta$ is weakly expressed [20]. HNF1 $\beta$ inactivation has been linked to EMT in ovarian cancer [34]. Ovarian carcinoma cell lines where HNF1 $\beta$ function was knockdown by siRNA or transfection with a dominant-negative mutant showed reduced E-cadherin expression and underwent epithelial-mesenchymal-like transition, associated with Slug overexpression. HNF1 $\beta$ overexpression lead to down-regulation of Snail and Slug expression. In ovarian tumors, expression of HNF1 $\beta$ was associated with Ecadherin. Altogether, these results support a role of HNF1 $\beta$ in the maintenance of epithelial phenotype. As HNF1 $\alpha$ and $\beta$ have very close activity and can recognize the same genes, HNF1 $\alpha$ inactivation in hepatocytes could trigger the same reactions.

Repression of E-cadherin and other epithelial markers by HNF1 $\alpha$ could also go through other molecules regulated by HNF1 $\alpha$. In particular, EMT regulators Snail1/2 and ZEB1/2 are able to repress E-cadherin expression 


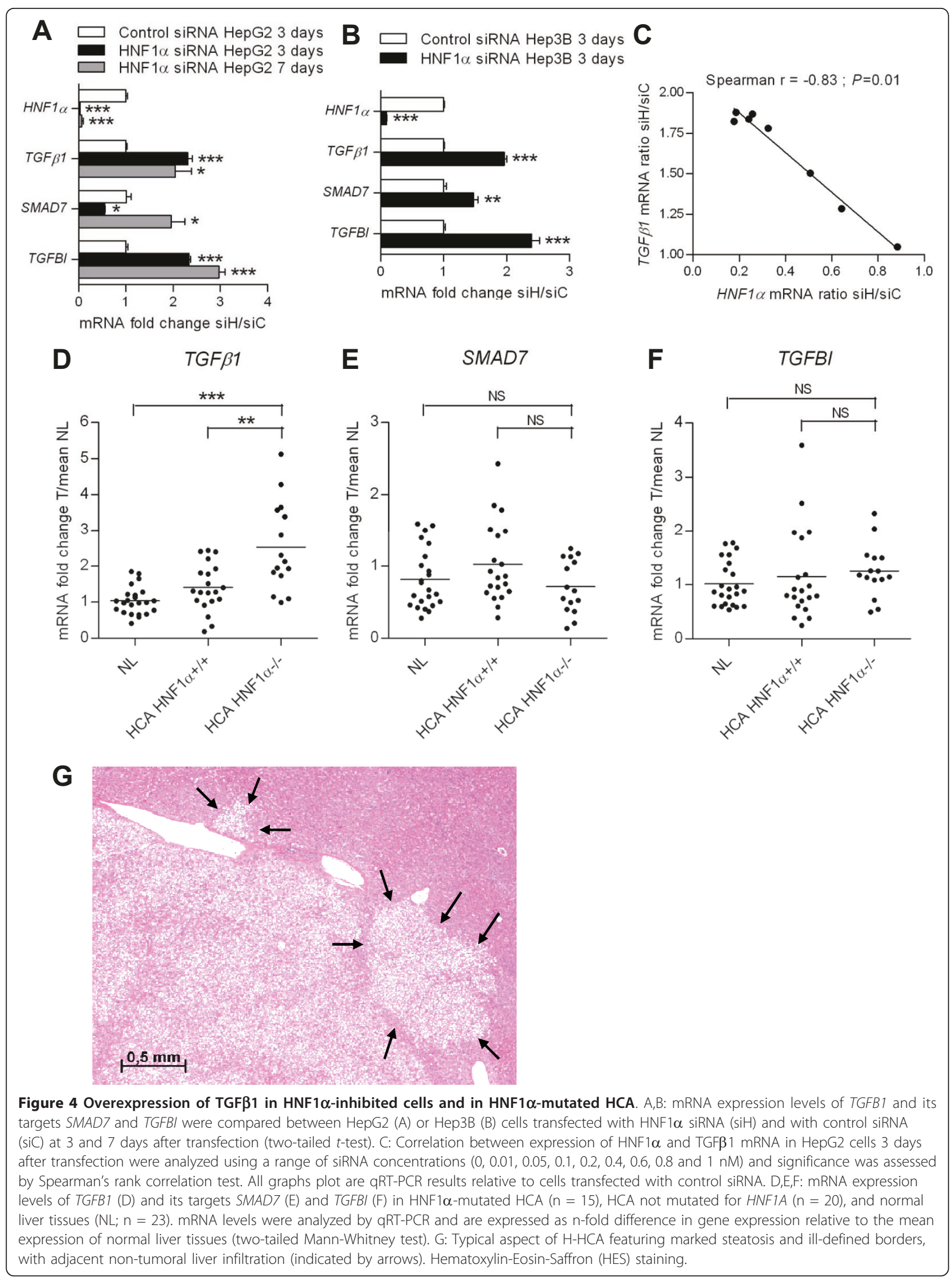


through interaction with specific E-boxes of the E-Cadherin promoter $[35,36]$. Snail1 has recently been shown to be repressed by HNF1 $\alpha$ in hepatocytes, through binding of HNF1 $\alpha$ to a consensus site in Snail1 promoter [37]. HNF1 $\alpha$ can repress Snail1 expression alone or in cooperation with $\mathrm{HNF} 4 \alpha$, another important regulator of hepatocyte differentiation [37].

Hepatocyte differentiation is achieved through a complex network of cross regulation between transcription factors, especially between HNF1 $\alpha$ and HNF4 $\alpha$ [20]. There is a regulational hierarchy between those proteins since HNF4 $\alpha$ expression precedes that of HNF1 $\alpha$ and activates the expression of HNF1 $\alpha$ [38]. On the other hand, HNF $1 \alpha$ is also capable of activating $H N F 4 \alpha$ expression, which defines a regulatory loop assuring the expression of HNF $1 \alpha$ and HNF $4 \alpha$ in hepatocytes $[21,39]$. Moreover, HNF1 $\alpha$ can repress its own expression and the expression of other targets of $H N F 4 \alpha$, through interaction with HNF4 $\alpha$ [40]. HNF4 $\alpha$ has been involved in epithelium formation and it has been shown to regulate the expression of several epithelial markers and components of cell junctions $[41,42]$. HNF4 $\alpha$ has been recently shown to negatively regulate mesenchymal molecules (vimentin, fibronectin and desmin) and EMT master regulator Snail1 [37]. Moreover, HNF4 $\alpha$ inactivation induces EMT in embryonic mouse kidneys [43]. Interestingly, HNF1 $\alpha$ seems to cooperate with HNF4 $\alpha$ to suppress mesenchymal markers expression as well as Snail1 [37]. Since HNF $4 \alpha$ was down-regulated in HNF1 $\alpha$-inhibited hepatocytes, the EMT observed in these cells could also go partially through HNF $4 \alpha$ inhibition.

Genes involved in cell mobility are also up regulated in HNF1 $\alpha$-inhibited cells, like metalloproteinases, but also PDGFA and $B$, which have been previously described as over expressed in HNF1 $\alpha$-inactivated tumors and cell lines [17]. PDGF growth factors are involved in angiogenesis but they are also autocrine factors involved in EMT and are necessary for TGF $\beta$ induced migration and tumor progression in hepatocytes $[25,44]$. Our results show that the EMT induced by HNF1 $\alpha$ inhibition is associated with increased cell migration.

To induce EMT, HNF1 $\alpha$ could also control directly the expression of growth factors capable of inducing EMT. Among those factors, we showed that TGF $\beta 1$ was up-regulated in cells transfected with HNF $1 \alpha$ siRNA and that the expression of TGF $\beta 1$ was inversely correlated to the expression of HNF1 $\alpha$, suggesting close regulation. Yet it is not clear whether it is this overexpression that trigger the EMT observed in these cells or not. In particular, TGF $\beta$ can induce the under expression of HNF4 $\alpha$ in rat primary hepatocytes and in immortalized murine hepatocytes [45]. Therefore,
HNF4 $\alpha$ down regulation in HNF1 $\alpha$-inhibited cells could also be due to TGF $\beta 1$ over-expression. Further studies are necessary to understand the role of TGF $\beta 1$ overexpression in the development of EMT induced by HNF1 $\alpha$ inhibition.

Interestingly, we also found an overexpression of TGF $\beta 1$ in HNF1 $\alpha$-mutated HCA, but neither SMAD7 nor TGFBI up-regulation, nor changes in TGF $\beta$-activation markers. Moreover, an analysis of H-HCA transcriptome failed to identify a TGF $\beta$ signature in $\mathrm{H}$ HCA, whether early or late, as defined by Courlouarn et al. [26] (data not shown). In particular we didn't identify any change in the expression of EMT markers at the transcriptional level in H-HCA. Neither could we analyze the expression of EMT markers at the borders of these tumors by immunostaining because of the important steatosis observed in H-HCA that makes the staining in tumors highly heterogeneous. However, H-HCA present ill-defined borders, that look like local invasions of the adjacent non tumor liver, which is compatible with EMT (Figure 4G).

The role of TGF $\beta 1$ overexpression in these benign tumors remains unclear. TGF $\beta$ has a dual effect on tumor development. In early carcinogenesis, TGF $\beta$ activation induces cell death and in late carcinogenesis, it is involved in invasion and EMT development [46]. In tumorous cell lines, cells are at a late stage of carcinogenesis and therefore TGF $\beta$ is prone to induce EMT. Whereas in benign tumors, we could think that TGF $\beta$ overexpression would induce apoptosis but HNF1 $\alpha$ mutated HCA do not show important necrosis and transcriptomic analysis did not reveal important changes in genes involved in apoptosis or cell cycle arrest $[17,18]$. In the liver, TGF $\beta$ has also been involved in hepatic differentiation and fibrosis $[47,48]$. HNF1 $\alpha$-mutated adenomas are developed in normal livers and do not show fibrosis, so this aspect of TGF $\beta$ is irrelevant, but HNF1 $\alpha$ and TGF $\beta$ are both involved in hepatic differentiation. TGF $\beta$ pathway is involved in several steps of liver development, in particular in hepatoblast proliferation and differentiation $[48,49]$. Weak TGF $\beta$ concentrations are needed for hepatoblast differentiation into hepatocytes. As $\mathrm{HNF} 1 \alpha$ is involved in late hepatocyte differentiation, we suggest that HNF1 $\alpha$ negative control of TGF $\beta 1$ expression could be associated with establishment/maintenance of hepatocyte differentiation and arrest of proliferation.

\section{Conclusion}

In conclusion, our study shows that HNF1 $\alpha$ loss can lead to epithelial-mesenchymal transition in liver cancer cell lines, with E-cadherin repression, TGF $\beta 1$ overexpression and increased migration abilities. This result suggests that HNF1 $\alpha$ could be involved in maintenance 
of epithelial phenotype in these cell lines and gives new insight in understanding the mechanism related to HNF1 $\alpha$ inactivation.

\section{Additional material}

\section{Additional file 1: TaqMan ${ }^{\circledR \oplus}$ pre-designed gene expression assays} Additional file 2: Expression of HNF1 $\beta$ and HNF4 $\alpha$ after inhibition of HNF1 $\alpha$ expression in HepG2 cells. A: HepG2 cells were transfected independently with siRNA directed against exons 8 and 9 of HNF1 $\alpha(\mathrm{siH})$, or with a control siRNA ( $\mathrm{siC}$ ). Inhibition efficiencies were assessed at 0, 1 and 2 days after transfection by measuring the expression level of HNFTA and of its transactivated gene (FABP1) by qRT-PCR. Expression of homologue HNF1 $\beta$ was measured to assess the specificity of HNF1 $\alpha$ siRNA, and HNF4 $\alpha$ expression was also measured (two-tailed $t$-test). B Correlations between expression of HNF1 $\alpha$ and HNF4 $\alpha$ mRNA were analyzed using a range of siRNA concentrations $(0,0.01,0.05,0.1,0.2,0.4$, $0.6,0.8,1,5,10$ and $50 \mathrm{nM})$ and significance was assessed by Spearman's rank correlation test. All graphs plot are qRT-PCR results relative to cells transfected with control siRNA.

Additional file 3: E-cadherin expression is correlated to HNF1 $\alpha$ expression. Correlations between expression of HNF1A and CDH1 were analyzed using a range of siRNA concentrations $(0,0.01,0.05,0.1,0.2,0.4$, $0.6,0.8,1,5,10$ and $50 \mathrm{nM})$ and significance was assessed by Spearman's rank correlation test. All graphs plot are $q R T-P C R$ results relative to cells transfected with control siRNA.

\section{List of Abbreviations}

HNF1a: Hepatocyte nuclear factor 1 alpha; HCA: Hepatocellular Adenoma; HHCA: HNF1a-mutated Hepatocellular Adenoma; qRT-PCR: Quantitative Reverse Transcription-PCR; EMT: Epithelial-mesenchymal transition; TGF $\beta$ : Transforming growth factor beta

\section{Acknowledgements}

This work was supported by the ARC (Association pour la Recherche sur le Cancer, grant 3194), Biolntelligence (OSEO), the LABEX Immuno-Oncology and the INCa (Institut national du Cancer, grant: PAIR-HCC "NoFLIC"). LP was supported by a MERT doctoral fellowship.

\section{Author details}

${ }^{1}$ Inserm U674 Génomique fonctionnelle des tumeurs solides, Paris, France. ${ }^{2}$ Faculté de Médecine, Université Paris Descartes, Paris, France. ${ }^{3}$ UMR 144, Institut Curie, Paris, France. ${ }^{4}$ Inserm U889, Université Bordeaux 2, Bordeaux, France. ${ }^{5}$ Pathlogy department, CHU Bordeaux Hôpital Pellegrin, Bordeaux, France. ${ }^{6}$ Oncology department, Hôpital européen Georges Pompidou HEGP, AP-HP, Paris, France.

\section{Authors' contributions}

LP, SR, DV, JZR contributed to study concept and design, data acquisition, and data analysis. PBS contributed to data acquisition and data analysis. LP has drafted the manuscript and all other authors critically reviewed the manuscript. All authors gave final approval of the version to be published.

\section{Competing interests}

The authors declare that they have no competing interests.

Received: 4 April 2011 Accepted: 5 October 2011 Published: 5 October 2011

\section{References}

1. Courtois G, Morgan JG, Campbell LA, Fourel G, Crabtree GR: Interaction of a liver-specific nuclear factor with the fibrinogen and alpha 1-antitrypsin promoters. Science 1987, 238(4827):688-692.

2. Odom DT, Zizlsperger N, Gordon DB, Bell GW, Rinaldi NJ, Murray HL, Volkert TL, Schreiber J, Rolfe PA, Gifford DK, et al: Control of pancreas and liver gene expression by HNF transcription factors. Science 2004, 303(5662):1378-1381.

3. Pontoglio M, Barra J, Hadchouel M, Doyen A, Kress C, Bach JP, Babinet C, Yaniv M: Hepatocyte nuclear factor 1 inactivation results in hepatic dysfunction, phenylketonuria, and renal Fanconi syndrome. Cell 1996, 84(4):575-585.

4. Shih DQ, Bussen M, Sehayek E, Ananthanarayanan M, Shneider BL, Suchy FJ, Shefer S, Bollileni JS, Gonzalez FJ, Breslow JL, et al: Hepatocyte nuclear factor-1alpha is an essential regulator of bile acid and plasma cholesterol metabolism. Nat Genet 2001, 27(4):375-382.

5. Lee YH, Sauer B, Gonzalez FJ: Laron dwarfism and non-insulin-dependent diabetes mellitus in the Hnf-1alpha knockout mouse. Mol Cell Biol 1998, 18(5):3059-3068.

6. Edmondson HA, Henderson B, Benton B: Liver-cell adenomas associated with use of oral contraceptives. N Engl J Med 1976, 294(9):470-472.

7. Bluteau O, Jeannot E, Bioulac-Sage P, Marques JM, Blanc JF, Bui H, Beaudoin JC, Franco D, Balabaud C, Laurent-Puig P, et al: Bi-allelic inactivation of TCF1 in hepatic adenomas. Nat Genet 2002, 32(2):312-315.

8. Zucman-Rossi J, Jeannot E, Nhieu JT, Scoazec JY, Guettier C, Rebouissou S, Bacq Y, Leteurtre E, Paradis V, Michalak S, et al: Genotype-phenotype correlation in hepatocellular adenoma: new classification and relationship with HCC. Hepatology 2006, 43(3):515-524.

9. Bioulac-Sage P, Rebouissou S, Thomas C, Blanc JF, Saric J, Sa Cunha A, Rullier A, Cubel G, Couchy G, Imbeaud S, et al: Hepatocellular adenoma subtype classification using molecular markers and immunohistochemistry. Hepatology 2007, 46(3):740-748.

10. Rebouissou S, Amessou M, Couchy G, Poussin K, Imbeaud S, Pilati C, Izard T, Balabaud C, Bioulac-Sage P, Zucman-Rossi J: Frequent in-frame somatic deletions activate gp130 in inflammatory hepatocellular tumours. Nature 2009, 457(7226):200-204

11. Nault JC, Fabre M, Couchy G, Pilati C, Jeannot E, Van Nhieu JT, SaintPaul MC, De Muret A, Redon MJ, Buffet C, et al: GNAS-activating mutations define a rare subgroup of inflammatory liver tumors characterized by STAT3 activation. J Hepatol 2011.

12. Pilati C, Amessou M, Bihl MP, Balabaud C, Nhieu JT, Paradis V, Nault JC, Izard T, Bioulac-Sage P, Couchy G, et al: Somatic mutations activating STAT3 in human inflammatory hepatocellular adenomas. J Exp Med 2011, 208(7):1359-1366.

13. Bacq Y, Jacquemin E, Balabaud C, Jeannot E, Scotto B, Branchereau S, Laurent C, Bourlier P, Pariente D, de Muret A, et al: Familial liver adenomatosis associated with hepatocyte nuclear factor 1alpha inactivation. Gastroenterology 2003, 125(5):1470-1475.

14. Flejou JF, Barge J, Menu Y, Degott C, Bismuth H, Potet F, Benhamou JP: Liver adenomatosis. An entity distinct from liver adenoma? Gastroenterology 1985, 89(5):1132-1138.

15. Reznik Y, Dao T, Coutant R, Chiche L, Jeannot E, Clauin S, Rousselot $P$, Fabre M, Oberti F, Fatome A, et al: Hepatocyte nuclear factor-1 alpha gene inactivation: cosegregation between liver adenomatosis and diabetes phenotypes in two maturity-onset diabetes of the young (MODY)3 families. J Clin Endocrinol Metab 2004, 89(3):1476-1480.

16. Jeannot E, Mellottee L, Bioulac-Sage P, Balabaud C, Scoazec JY, Tran Van Nhieu J, Bacq Y, Michalak S, Buob D, Laurent-Puig P, et al: Spectrum of HNF1A somatic mutations in hepatocellular adenoma differs from that in patients with MODY3 and suggests genotoxic damage. Diabetes 2010, 59(7):1836-1844.

17. Pelletier L, Rebouissou S, Paris A, Rathahao-Paris E, Perdu E, Bioulac-Sage $P$, Imbeaud S, Zucman-Rossi J: Loss of hepatocyte nuclear factor 1alpha function in human hepatocellular adenomas leads to aberrant activation of signaling pathways involved in tumorigenesis. Hepatology 2010, 51(2):557-566.

18. Rebouissou S, Imbeaud S, Balabaud C, Boulanger V, Bertrand-Michel J, Terce F, Auffray C, Bioulac-Sage P, Zucman-Rossi J: HNF1alpha inactivation promotes lipogenesis in human hepatocellular adenoma independently of SREBP-1 and carbohydrate-response element-binding protein (ChREBP) activation. J Biol Chem 2007, 282(19):14437-14446.

19. Rebouissou S, Vasiliu V, Thomas C, Bellanne-Chantelot C, Bui H, Chretien Y, Timsit J, Rosty C, Laurent-Puig P, Chauveau D, et al: Germline hepatocyte nuclear factor 1 alpha and 1 beta mutations in renal cell carcinomas. Hum Mol Genet 2005, 14(5):603-614. 
20. Kyrmizi I, Hatzis P, Katrakili N, Tronche F, Gonzalez FJ, Talianidis I: Plasticity and expanding complexity of the hepatic transcription factor network during liver development. Genes Dev 2006, 20(16):2293-2305.

21. Zhong W, Mirkovitch J, Darnell JE Jr: Tissue-specific regulation of mouse hepatocyte nuclear factor 4 expression. Mol Cell Biol 1994, 14(11):7276-7284.

22. Lee JM, Dedhar S, Kalluri R, Thompson EW: The epithelial-mesenchyma transition: new insights in signaling, development, and disease. J Cell Biol 2006, 172(7):973-981

23. Thiery JP: Epithelial-mesenchymal transitions in development and pathologies. Curr Opin Cell Biol 2003, 15(6):740-746.

24. Thiery JP, Sleeman JP: Complex networks orchestrate epithelialmesenchymal transitions. Nat Rev Mol Cell Biol 2006, 7(2):131-142.

25. Huber MA, Kraut N, Beug H: Molecular requirements for epithelialmesenchymal transition during tumor progression. Curr Opin Cell Biol 2005, 17(5):548-558.

26. Coulouarn C, Factor VM, Thorgeirsson SS: Transforming growth factor-beta gene expression signature in mouse hepatocytes predicts clinical outcome in human cancer. Hepatology 2008, 47(6):2059-2067.

27. Derynck R, Zhang YE: Smad-dependent and Smad-independent pathways in TGF-beta family signalling. Nature 2003, 425(6958):577-584.

28. Billings PC, Whitbeck JC, Adams CS, Abrams WR, Cohen AJ, Engelsberg BN, Howard PS, Rosenbloom J: The transforming growth factor-beta-inducible matrix protein (beta)ig-h3 interacts with fibronectin. J Biol Chem 2002, 277(31):28003-28009.

29. Yamagata K, Nammo T, Moriwaki M, Ihara A, lizuka K, Yang Q, Satoh T, Li M, Uenaka R, Okita K, et al: Overexpression of dominant-negative mutant hepatocyte nuclear fctor- 1 alpha in pancreatic beta-cells causes abnormal islet architecture with decreased expression of E-cadherin, reduced beta-cell proliferation, and diabetes. Diabetes 2002, 51(1):114-123.

30. Sakaguchi T, Gu X, Golden HM, Suh E, Rhoads DB, Reinecker HC: Cloning of the human claudin-2 5 -flanking region revealed a TATA-less promoter with conserved binding sites in mouse and human for caudal-related homeodomain proteins and hepatocyte nuclear factor-1alpha. J Biol Chem 2002, 277(24):21361-21370.

31. Koffler LD, Fernstrom MJ, Akiyama TE, Gonzalez FJ, Ruch RJ: Positive regulation of connexin32 transcription by hepatocyte nuclear factor1alpha. Arch Biochem Biophys 2002, 407(2):160-167.

32. Bach I, Mattei MG, Cereghini S, Yaniv M: Two members of an HNF1 homeoprotein family are expressed in human liver. Nucleic Acids Res 1991, 19(13):3553-3559.

33. De Simone V, De Magistris L, Lazzaro D, Gerstner J, Monaci P, Nicosia A, Cortese R: LFB3, a heterodimer-forming homeoprotein of the LFB1 family, is expressed in specialized epithelia. EMBO J 1991, 10(6):1435-1443.

34. Tomassetti A, De Santis G, Castellano G, Miotti S, Mazzi M, Tomasoni D, Van Roy F, Carcangiu ML, Canevari S: Variant HNF1 modulates epithelial plasticity of normal and transformed ovary cells. Neoplasia 2008, 10(12):1481-1492, 1483p following 1492.

35. Nieto MA: The snail superfamily of zinc-finger transcription factors. Nat Rev Mol Cell Biol 2002, 3(3):155-166.

36. Peinado $\mathrm{H}$, Portillo $\mathrm{F}$, Cano A: Transcriptional regulation of cadherins during development and carcinogenesis. Int J Dev Biol 2004, 48(56):365-375.

37. Santangelo L, Marchetti A, Cicchini C, Conigliaro A, Conti B, Mancone C, Bonzo JA, Gonzalez FJ, Alonzi T, Amicone L, et al: The stable repression of mesenchymal program is required for hepatocyte identity: A novel role for hepatocyte nuclear factor 4alpha. Hepatology 2011.

38. Kuo CJ, Conley PB, Chen L, Sladek FM, Darnell JE Jr, Crabtree GR: A transcriptional hierarchy involved in mammalian cell-type specification. Nature 1992, 355(6359):457-461.

39. Bailly A, Spath G, Bender V, Weiss MC: Phenotypic effects of the forced expression of HNF4 and HNF1alpha are conditioned by properties of the recipient cell. J Cell Sci 1998, 111(Pt 16):2411-2421.

40. Ktistaki E, Talianidis I: Modulation of hepatic gene expression by hepatocyte nuclear factor 1. Science 1997, 277(5322):109-112.

41. Battle MA, Konopka G, Parviz F, Gaggl AL, Yang C, Sladek FM, Duncan SA: Hepatocyte nuclear factor 4alpha orchestrates expression of cell adhesion proteins during the epithelial transformation of the developing liver. Proc Natl Acad Sci USA 2006, 103(22):8419-8424.
42. Spath GF, Weiss MC: Hepatocyte nuclear factor 4 provokes expression of epithelial marker genes, acting as a morphogen in dedifferentiated hepatoma cells. J Cell Biol 1998, 140(4):935-946.

43. Kanazawa T, Ichii O, Otsuka S, Namiki Y, Hashimoto Y, Kon Y: Hepatocyte Nuclear Factor 4 Alpha Is Associated with Mesenchymal-Epithelial Transition in Developing Kidneys of C57BL/6 Mice. J Vet Med Sci 2010.

44. Gotzmann J, Fischer AN, Zojer M, Mikula M, Proell V, Huber H, Jechlinger M, Waerner T, Weith A, Beug H, et al: A crucial function of PDGF in TGF-betamediated cancer progression of hepatocytes. Oncogene 2006, 25(22):3170-3185.

45. Cicchini C, Filippini D, Coen S, Marchetti A, Cavallari C, Laudadio I, Spagnoli FM, Alonzi T, Tripodi M: Snail controls differentiation of hepatocytes by repressing HNF4alpha expression. J Cell Physiol 2006, 209(1):230-238.

46. Heldin CH, Landstrom M, Moustakas A: Mechanism of TGF-beta signaling to growth arrest, apoptosis, and epithelial-mesenchymal transition. Curr Opin Cell Biol 2009, 21(2):166-176.

47. Inagaki Y, Okazaki I: Emerging insights into Transforming growth factor beta Smad signal in hepatic fibrogenesis. Gut 2007, 56(2):284-292.

48. Lemaigre FP: Mechanisms of liver development: concepts for understanding liver disorders and design of novel therapies. Gastroenterology 2009, 137(1):62-79.

49. Clotman F, Lemaigre FP: Control of hepatic differentiation by activin/ TGFbeta signaling. Cell Cycle 2006, 5(2):168-171.

\section{Pre-publication history}

The pre-publication history for this paper can be accessed here: http://www.biomedcentral.com/1471-2407/11/427/prepub

doi:10.1186/1471-2407-11-427

Cite this article as: Pelletier et al.: HNF1 $\alpha$ inhibition triggers epithelialmesenchymal transition in human liver cancer cell lines. BMC Cancer 2011 11:427.

\section{Submit your next manuscript to BioMed Central and take full advantage of:}

- Convenient online submission

- Thorough peer review

- No space constraints or color figure charges

- Immediate publication on acceptance

- Inclusion in PubMed, CAS, Scopus and Google Scholar

- Research which is freely available for redistribution

Submit your manuscript at www.biomedcentral.com/submit
C Biomed Central 